\title{
KONTRA-RADIKALISASI AGAMA PUSAT STUDI AL-QUR'AN JAKARTA
}

\author{
Kurdi Fadal \\ Institut Agama Islam Negeri Pekalongan \\ kurdi_fadal@yahoo.com
}

\begin{abstract}
This paper describes the effort of the Center for Qur'anic Studies (PSQ) Jakarta in counter-radicalism by mediating the Islamic moderation. The initiated programs of the PSQ have been managed for making an equilibrium of the radical movement in the Muslim community. The research argues that the PSQ emphasizes a soft approach to counterradicalisation by delving into the Quranic values of moderation and tolerance. There are two primary programs of the PSQ: caderization (as a prospective mufasir) and direct preaching. The programs involve various segments of communities conforming to their educational levels or competencies in the Quranic studies. Education for Young Exegetes (Pendidikan Kader Mufasir: PKM) is an important program for master and doctoral students in writing their thesis; Post-Memorization of the Quran (Pasca-Tahfidz) is a program for those who commit to memorize the Quran; the Daurah Bidayatul Mufassir program for undergraduate students; the Training of Trainer (ToT) program for teachers of the Quran and Islamic preachers; and the Living Quran for high school students. The direct preaching program is designed to provide guidance and assistance to the community in the Friday preaching sermons, seminars, and religious teachings.
\end{abstract}

Keywords: Counter-radicalisation, Islamic moderation, Quranic exegesis.

Abstrak: Tulisan ini mengkaji tentang upaya kontra-radikalisasi PSQ (Pusat Studi Al-Qur'an) Jakarta melalui program moderasi Islam. Program tersebut dilakukan untuk mengimbangi maraknya radikalisasi atas nama Islam di kalangan masyarakat Muslim Indonesia. Artikel ini berargumen bahwa PSQ menekankan bentuk soft approach dalam melakukan upaya kontra-radikalisasi dengan menggali nilai-nilai Alquran yang mengedepankan moderasi, toleransi dan kesantunan. Ada dua program utama kontra-radikalisasi PSQ yaitu program kaderisasi dan pembinaan langsung. Program tersebut dilaksanakan secara periodik dan fokus sasarannya menyesuaikan tingkat pendidikan atau pemahaman masyarakat tentang Islam, khususnya tafsir Alquran. Pendidikan Kader Mufasir merupakan program kaderisasi untuk mahasiswa S2 dan S3 yang sedang menyelesaikan tesis dan disertasi; 
Pesantren pasca-tahfidz bagi kalangan penghafal Alquran; Daurah Bidayatul Mufassir untuk mahasiswa S1; Training of Trainer bagi para dai, pengajar dan guru tafsir, dan Living Quran bagi para siswa sekolah. Program lainnya adalah pembinaan langsung kepada masyarakat umum berupa asistensi khutbah Jumat, ceramah pada seminar dan pengajian.

Kata Kunci: Kontra-radikalisasi, Moderasi Islam, Tafsir Alquran.

\section{Pendahuluan}

Secara doktrinal, Islam tidak mengajarkan kekerasan terhadap sesama maupun pihak agama lain. Karena itu, Bassam Tibi menilai bahwa radikalisme dalam Islam berakar dari faktor politik, bukan faktor teologis. ${ }^{1}$ Namun bagi Keppel Gilles, gerakan radikal Islam, yang ia sebut sebagai Jihadi Salafism, merupakan bentuk 'penghambaan' terhadap teks-teks suci dengan pemahaman yang paling literal. Dalam konteks global, Keppel melihat bahwa pemahaman literal itu berkombinasi dengan komitmen berjihad melawan Amerika sebagai sasaran utamanya. ${ }^{2}$ Pernyataan Keppel sealur dengan pernyataan Yūsuf al-Qaraḍ̄wī bahwa salah satu penyebab radikalisme agama adalah kedangkalan pemahaman terhadap esensi ajaran Islam. ${ }^{3}$

Dalam konteks Indonesia, gerakan radikalisme Islam semakin mendapat tempat bersamaan dengan euforia kebebasan era reformasi di negeri ini. ${ }^{4}$ Menurut Noorhaidi Hasan, gerakan radikalisme merupakan perwujudan dari meluasnya lanskap politik Indonesia pasca-Orde Baru. Sebagian masih menggunakan nama asli gerakan asalnya, namun sebagian yang lain hanya meminjam semangat ideologinya. Sifat dari gerakan yang ditunjukkan juga cukup beragam. ${ }^{5}$ Berbagai gerakan radikalisme yang tumbuh di Indonesia memiliki potensi melahirkan aksi-aksi terorisme. Bahkan dalam catatan Endy Haryono, aksi-aksi terorisme di Indonesia meningkat drastis pasca

\footnotetext{
1 Bassam Tibi, "Islamism and Democracy: On the compatibility of institutional Islamism and the political culture of democracy," dalam Totalitarian Movements and Political Religions, vol. 10, no. 2 (2009), 137.

2 Kepel Gilles, Jihad: The Trail of Political Islam (London: I.B. Tauris, 2002).

3 Yūsuf al-Qaraḍāwī, Al-Saḅwah al-Islāmìyah bayn al-Jubūd wa al-Tatarruf (Kairo: alTaqwā, 2001), 61-64.

${ }^{4}$ Noorhaidi Hasan, Laskar Jihad: Islam, Militancy, and the Quest for Identity in Post-New Order Indonesia (Ithaca: Cornell Southeast Asia Program Publications, 2006), 13-25.

5 Noorhaidi Hasan, Laskar Jihad: Islam, Militansi dan Pencarian Identitas di Indonesia Pasca Orde Baru, terj. Hairus Salim (Jakarta: LP3ES, 2008), 322.
} 
Orde Baru. Haryono mencatat sejak tahun 1999 hingga 2009 telah terjadi aksi terorisme sebanyak dua puluh tujuh kali yang terjadi di berbagai tempat. ${ }^{6}$ Pada tahun-tahun berikutnya, aksi-aksi terorisme masih saja terjadi. Misalnya pada tahun 2016, pihak kepolisian menangani 170 kasus terorisme, yang naik drastis dari tahun sebelumnya sebanyak 82 kasus. Pada tahun 2017 dilaporkan terdapat 172 orang tersangka kasus terorisme.

Kelompok radikal dipastikan masih tetap ada dan terus menyebarkan paham radikalisme. Terbukti pada beberapa tahun terakhir ratusan orang tertangkap. Mereka dengan fasih menggunakan dalil-dalil agama untuk mempromosikan ideologinya. Ayat-ayat Alquran mereka pahami secara dangkal, sempit dan kaku tanpa memperhatikan konteks dan substansi maknanya. Sehingga paham yang dihasilkan bertentangan dengan nilai-nilai ajaran Islam. ${ }^{8}$ Corak pemahaman semacam ini dipromosikan kepada masyarakat di berbagai tempat belajar, seperti lembaga pendidikan, rumah ibadah (baca: masjid) dan forum-forum pengajian. Lembaga pendidikan seharusnya menjadi tempat mengajarkan pemahaman Islam yang toleran dan moderat, namun di beberapa tempat lembaga semacam ini justru menjadi "kiblat" suburnya pemahaman radikalisme. ' Demikian pula, masjid yang seharusnya menjadi tempat ibadah bagi masyarakat dan sarana belajar agama secara benar bagi mereka, justru beralih fungsi menjadi tempat bagi proses ideologisasi paham radikal, doktrinasi ajaran kekerasan dan pandangan kebencian serta pemahaman keagamaan yang sempit. ${ }^{1}$

Model pemahaman keagamaan sejatinya bukan faktor fundamental lahirnya radikalisme dalam Islam. Faktor ketidakadilan,

6 Endy Haryono, "Kebijakan Anti-Terorisme Indonesia: Dilema Demokrasi dan Represi," dalam Jurnal Ilmu Sosial dan Ilmu Politik, vol. 14, no. 2 (2010), 232-235.

7 Ambaranie Nadia Kemala Movanita, "Pelaku Teror Tahun 2017 Meningkat, Dua di Antaranya Lakukan Bom Bunuh Diri," dalam https://nasional.kompas.com/read/2017/12/29/14252371/pelaku-teror-tahun2017-meningkat-dua-di-antaranya-lakukan-bom-bunuh-diri. Diakses Tanggal 20 April 2018.

8 Nuhrison M. Nuh (ed.), Peranan Pesantren dalam Mengembangkan Budaya Damai (Jakarta: Badan Litbang dan Diklat Kementerian Agama, 2010), 21.

9 Abu Rokhmad, "Radikalisme dan Upaya Deradikalisasi Paham Radikal," dalam Walisongo: Jurnal Penelitian Sosial Keagamaan, vol. 20, no. 1 (2012), 80.

10 Agus Sunaryo, "Masjid dan Ideologisasi Radikaslisme Islam: Menyoal Peran masjid sebagai Media Transformasi Ideologi," dalam Akademika: Jurnal Pemikiran Islam, vol. 22, no. 1 (2017), 233-234. 
ketimpangan sosial ekonomi, sosial dan politik menjadi alasan utamanya. Kaum radikal menjadikan teks-teks keagamaan sebagai justifikasi dari paham radikalisme. Azra melihat ada fenomena yang terjadi di Indonesia pasca reformasi. Ia menyebut fenomena tersebut dengan mainstream Muslims, yang disebut dengan kelompok moderat dan kelompok radikal. Keduanya saling berbenturan satu sama lain. Solusi yang Azra berikan adalah pentingnya memberdayakan kelompok moderat sebagai upaya menanggulangi kelompok radikal. ${ }^{11}$

Tulisan ini hendak menghadirkan Pusat Studi Al-Qur'an (PSQ) sebagai sebuah entitas kelompok Muslim yang dipandang moderat dan memiliki beberapa program untuk membendung radikalisasi. Menurut menulis, berbagai program penguatan moderasi Islam yang dilakukan Pusat Studi Al-Qur'an (PSQ) adalah bagian dari kontraradikalisasi untuk membendung pemahaman radikal di masyarakat. Tulisan ini hendak menegaskan bahwa penguatan pemahaman bidang tafsir Alquran menjadi fondasi untuk melawan radikalisasi atas nama agama. Dengan demikian, kajian ini diharapkan mampu memberikan inspirasi kepada para pihak akademisi maupun pemerintah agar kontra radikalisasi terus dilakukan melalui peneguhan moderasi Islam di berbagai level masyarakat.

\section{Radikalisme dan Tafsir Agama}

Menurut Yūsuf al-Qaraḍ̄āī, radikalisme agama disebabkan oleh beberapa faktor, salah satunya karena kedangkalan pemahaman terhadap esensi ajaran Islam. Kedangkalan pemahaman terjadi dalam beberapa bentuk: 1) hanya memilih ayat-ayat yang mendukung sikap dan pemikiran radikal namun mengabaikan ayat-ayat lain yang memberi pesan sebaliknya; (2) cenderung mengabaikan latar belakang turunnya ayat sehingga kesimpulan pemahamannya bersifat tekstual, rigid dan bias; dan (3) truth claim, yakni menganggap sebuah pemahaman sebagai satu-satunya kebenaran sementara menilai pemahaman lain salah. ${ }^{12}$

\footnotetext{
11 Azyumardi Azra, "Indonesian Islam, Mainstream Muslims And Politics." Artikel dipresentasi pada Konferensi Taiwanese and Indonesian Islamic Leaders Exchange Project, Taipei, 2006.

12 Al-Qaradāwī, Al-Saḥwah al-Islāmìyah, 61-64.
} 
Tafsir keagamaan radikal umumnya bisa dilihat dari beberapa ciri. ${ }^{13}$ Pertama, menafsirkan ayat dan hadis secara tekstual, khususnya mengenai tema-tema seputar hubungan sosial, prilaku keagamaan, dan jinayah. Pendukung corak tafsir semacam ini tidak menerima model tafsir rasional-kontekstual. Mereka juga menolak segala bentuk prilaku sosial dan aturan yang tidak memiliki rujukan eksplisit dalam teks suci agama.

Kedua, menyuarakan pemberlakuan syariat Islam secara kafah. Ciri ini sebagai konsekuensi dari ciri pertama di atas. Ketika mereka hanya menerima model berprilaku ala Qurani-Sunnah versi mereka, maka model yang lain diyakini salah dan tidak Islami. Mereka menolak keras sistem negara demokrasi yang tak memiliki rujukan tekstual dari Nabi dan generasi awal Islam. Bagi mereka, visi Islam adalah integrasi antara urusan agama, duniawi, dan dawlah (negara). ${ }^{14}$ Puncak dari perjuangan mereka adalah pendirian negara Islam.

Ketiga, sikap intoleran terhadap pihak lain yang tidak sepenafsiran. Mereka enggan menerima kebenaran dari pihak lain yang berseberangan. Sikap ini juga dilengkapi dengan sikap eksklusif dan tidak mau menerima yang lain. Mereka hanya memiliki pandangan hitam-putih dalam beragama dan bermasyarakat: benar-salah, halalharam, iman-kufur, Islam-tagut.

Keempat, berpandangan revolusioner atas hasil penafsiran yang dipilih. Ketika yang diyakini hanya ada halal-haram, iman-kufur, Islam-tagut, maka mereka hanya akan memperjuangkan bagaimana yang halal dilaksanakan dan yang haram diberantas, yang mencerminkan keimanan sejati terus disuarakan dan diaplikasikan dan yang kufur dihanguskan, serta sistem kehidupan yang sejalan dengan ajaran Islam akan selalu menjadi prinsip yang harus disuarakan dan dipaksakan sementara yang tagut wajib ditolak. Namun, semua itu hanya mengacu pada produk penafsiran versi mereka.

Pemahaman keagamaan yang eksklusif-radikal banyak bermunculan di Indonesia. Hal itu ditandai dengan merebaknya isuisu sosial politik yang dihubungkan dengan ajaran agama secara ideologis. Kepemimpinan perempuan, pemberlakuan syariat Islam

\footnotetext{
13 Toto Suharto dan Ja'far Assaqaf, "Membendung Arus Paham Keagamaan Radikal di Kalangan Mahasiswa PTKIN," dalam Al-Tahrir Jurnal Pemikiran Islam, vol. 14, no. 1 (2014), 162-163.

14 Masdar Hilmy, "The Politics of Retaliation: the Backlash of Radical Islamists to Deradicalization Project in Indonesia," dalam Al-Jami'ab: Journal of Islamic Studies, vol. 51, no. 1 (2013), 133.
} 
dan sistem khilafah, adalah sebagian isu yang banyak bergulir dalam percaturan politik tanah air. Memang, tidak bisa dinilai salah jika sebagian kelompok meyakini perempuan tidak boleh tampil sebagai pemimpin seperti presiden, gubernur atau bupati. Akan tetapi, ketika ide dan pemahaman tersebut dipaksakan penerapannya melalui demonstrasi penolakan, atau sikap truth claim dengan menilai pihakpihak yang tidak setuju sebagai 'tidak Islami' dan dianggap telah menentang Alquran dan Islam, maka persoalannya bukan lagi pada pertarungan ide namun mengarah pada lahirnya turbulensi dalam kehidupan bermasyarakat, beragama dan bernegara. Karena, pemaksaan kehendak tersebut cenderung beralih ke tindakan-tindakan ekstremis, lebih-lebih ketika tindakan itu dilakukan atas nama Islam.

Begitu pula dengan gagasan pemberlakuan syariat Islam. Sebagian orang atau kelompok merasa yakin bahwa syariat Islam wajib diberlakukan di Indonesia. Gagasan ini banyak disuarakan di Indonesia sejak awal berdirinya bangsa ini dan kembali didengungkan pasca era reformasi. Selain itu, sistem khilafah juga menjadi gagasan yang diusung sebagian kelompok berpaham radikal. Namun, ketika gagasan itu disuarakan disertai gerakan nyata di masyarakat, maka akan terjadi turbulensi bagi kehidupan berbangsa dan bernegara dalam konteks Indonesia. Menyuarakan gagasan al-khiläfah al-islämiyah berarti hendak mengganti sistem yang telah menjadi konsensus bangsa Indonesia, yaitu Pancasila. Situasi akan lebih parah ketika Pancasila dan sistem demokrasi di negara ini dinilai sebagai sistem kafir dan tidak sesuai dengan ajaran Islam hakiki.

Menurut Azyumardi Azra, radikalisme merupakan bentuk ekstrem dari revivalisme, namun keduanya berbeda dalam karakter. Revivalisme merupakan bentuk intensifikasi keislaman yang berorientasi ke dalam, yakni pengaplikasian dari sebuah kepercayaan yang hanya diterapkan untuk diri pribadi. Sementara radikalisme lebih berorientasi keluar yang dalam implementasinya sering menggunakan cara-cara kekerasan. ${ }^{15}$ Ekspresi ini dapat disebut dengan "Kemarahan Sakral". ${ }^{16}$ Mereka marah karena merasa ajaran agama yang diyakini telah ditinggalkan, kesejahteraan masyarakat sebagai tujuan utama dari

15 Azyumardi Azra, Islam Reformis: Dinamika Intelektual dan Gerakan (Jakarta: Raja Grafindo Persada, 1999), 46-47.

16 Thohir Yuli Kusmanto, Moh. Fauzi dan M. Mukhsin Jamil, "Dialektika Radikalisme dan anti-Radikalisme di Pesantren," dalam Walisongo Jurnal Penelitian Sosial Keagamaan, vol. 23, no. 1 (2015), 34. 
ajaran Islam diabaikan, dan pemberlakuan syariat Islam sebagai solusi dari problem tersebut tidak diterapkan.

\section{Radikalisasi, Deradikalisasi dan Kontra-Radikalisasi}

Radikalisasi (radicalization) berasal dari kata radix yang berarti: akar, pangkal, bagian bawah, menyeluruh, habis-habisan dan amat keras dalam menuntut perubahan. Dari kata radix turun menjadi beberapa istilah: radical (radikal), radicalism (radikalisme), dan radicalization (radikalisasi). Radical (radikal) adalah kata sifat yang bermakna: secara mendasar (sampai pada hal yang prinsip); amat keras menuntut perubahan (undang-undang, pemerintahan); maju dalam berpikir atau bertindak. Radicalism (radikalisme) berarti: 1) paham atau aliran yang radikal dalam politik; 2) paham atau aliran yang menginginkan perubahan atau pembaharuan sosial dan politik dengan cara kekerasan atau drastis; 3) sikap ekstrem dalam aliran politik. Sementara radicalization (radikalisasi) adalah proses, perbuatan meradikalkan. ${ }^{17}$

Tidak ada kata mufakat di kalangan para tokoh mengenai definisi 'radikalisasi'. Namun definisi yang lebih komplit adalah definisi yang ditawarkan oleh Charles E. Allen. Menurutnya, Radicalization is the process of adopting an extremist belief system, including the willingness to use, support, or facilitate violence as a method to effect societal change (Radikalisasi adalah proses mengadopsi sistem keyakinan ekstremis, termasuk kesediaan untuk menggunakan, mendukung, atau memfasilitasi kekerasan sebagai metode untuk mempengaruhi perubahan masyarakat). ${ }^{18}$ Di sisi lain, radikalisasi juga bisa dipahami sebagai proses depluralisasi individu terhadap konsep dan nilai-nilai politik seperti keadilan, demokrasi, dan kemerdekaan.

Tinka Veldhuis dan Staun mengemukakan, ada dua faktor utama terjadinya radikalisasi, yakni level makro dan mikro. Level mikro bisa dibagi menjadi faktor individu dan sosial. Faktor sosial adalah akibat dari bagaimana individu berada dalam struktur sosial yang terjadi melalui interaksi dan identifikasi sosial. Faktor individu terjadi karena pengalaman-pengalaman yang menyebabkan bagaimana orang-orang menerima atau merespon lingkungan sosial. Faktor-faktor level mikro

17 Tim Penyusun KBBI, Kamus Besar Bahasa Indonesia (Jakarta: Pusat Bahasa Depdiknas, 2008), 1511-2.

18 Dikutip dari Lorenzo Vidino dan James Brandon, Countering Radicalization in Europe (London: ICSR, 2012), 8. 
membentuk keadaan individu yang mengarah pada radikalisasi. Satu dengan lainnya bisa berbeda. ${ }^{19}$

Untuk mencegah terjadinya radikalisme dan maraknya proses radikalisasi, beberapa pihak harus berperan aktif melalui beberapa jalur, baik oleh pemerintah maupun para tokoh agama, baik atas nama individu maupun organisasi atau lembaga keagamaan. ${ }^{20}$ Semuanya dapat berperan dalam melakukan kontra-radikalisasi, deradikalisasi, rahabilitasi, atau reintegrasi.

Pemerintah Indonesia telah menetapkan peraturan untuk menanggulangi ekstremisme dan radikalisme. Kampanye anti terorisme dan radikalisme yang dilakukan pemerintah mulai mengemuka pasca terjadinya aksi teror pada kasus bom bunuh diri di tahun 2002. Kampanye itu diperkuat melalui Undang-Undang Nomor 15 tahun 2003 tentang Pemberantasan Tindak Pidana Terorisme. Melalui pendirian BNPT (Badan Negara Pemberantasan Terorisme), pemerintah berupaya melakukan pencegahan, perlindungan, deradikalisasi, penindakan dan penyiapan kesiapsiagaan nasional di bidang penanggulangan terorisme.

Dalam Peraturan Presiden Nomor 456 tahun 2010 ditetapkan tentang fungsi BNPT dalam penanganan radikalisme dan terorisme mengemban beberapa tugas termasuk: 1) memformulasikan kebijakan, strategi, program nasional tentang counter terorisme; 2) melakukan monitoring, analisis, dan evaluasi tentang counter terorisme; 3) melakukan koordinasi tentang implementasi pencegahan dan upaya melawan propaganda ideologi radikal untuk counter terorisme; dan 4) melakukan koordinasi tentang implementasi program deradikalisasi.

Dalam bidang pencegahan ini, BNPT menggunakan dua strategi: deradikalisasi dan kontra-radikalisi. Deradikalisasi merupakan strategi penanganan secara langsung kepada kelompok simpatisan, pendukung, inti, dan militan serta pihak yang terlibat dalam gerakan radikalisme dan terorisme. Deradikalisasi lebih bersifat recovery (penyembuhan) agar mereka meninggalkan cara-cara kekerasan dan teror dalam memperjuangkan misinya serta memoderasi paham-

19 Veldhuis dan Staun, Islamist Radicalisation: A Root Cause Model (Den Haag: Netherlands Institute of International Relations Clingendael, 2009), 62-65.

20 Ahmad Darmaji, "Pondok Pesantren dan Deradikalisasi Islam di Indonesia," dalam Millah Jurnal Studi Agama, vol. XI, No. 1 (2011). 
paham radikal yang sejalan dengan semangat kelompok Islam moderat. $^{21}$

Sedangkan kontra-radikalisasi dilakukan sebagai langkah preventif melalui penanaman nilai-nilai keagamaan dan ke-Indonesiaan nonkekerasan. Strategi ini dalam prosesnya dilakukan melalui pendidikan baik formal maupun non-formal. Kontra-radikalisasi lebih difokuskan pada masyarakat umum melalui kerjasama dengan tokoh agama, tokoh pendidikan, tokoh masyarakat, tokoh adat, tokoh pemuda dan stakeholder lain dalam menyebarluaskan nilai-nilai kebangsaan.

BNPT telah melakukan langkah-langkah kongkret kontraradikalisasi dengan turun ke lapangan, baik melalui seminar di kampus-kampus maupun melalui penyuluhan tentang bahaya radikalisme dan terorisme. Langkah itu dilakukan karena radikalisme lahir dari proses radikalisasi melalui ideologisasi paham-paham radikal kepada masyarakat, sehingga upaya yang ditempuh untuk mengimbanginya adalah melakukan counter terhadap pemahaman tersebut. $^{22}$

Penanganan terorisme oleh BNPT tidak hanya berupa penegakan dan penindakan hukum (hard power), namun juga melalui upaya pencegahan (soft power). Pendekatan secara soft mengacu pada keberhasilan membangun kepercayaan antara narapidana teroris dan teroris yang terlibat dalam kelompok jaringan radikal untuk mempengaruhi anggota lain untuk meninggalkan aksi-aksi kekerasan dan menghindari diri dari paham radikalisme. Contoh yang paling jelas adalah Nasir Abbas, seorang mantan anggota militan yang pernah beraksi di Afganistan. Abbas juga pernah melatih pelaku bom Bali pada 2002. Setelah bebas dari penjara pada 2004, Abbas ikut bergabung dalam program deradikalisasi pihak kepolisian. Ia juga ikut membantu melakukan pelacakan untuk upaya penangkapan kepada beberapa mantan kompatriotnya. Ia mengunjungi para mantan

21 Alex P. Schmid, Radicalisation, De-Radicalisation, Counter-Radicalisation: A Conceptual Discussion and Literature Review (Den-Haag, ICCT-The Hague, 2013), 51.

22 Tim BNPT, "Berikan Kuliah Umum di Universitas Andalas Kepala BNPT Ingatkan Ancaman Infiltrasi Ideologi Radikal Terorisme," dalam https://www.bnpt.go.id/berikan-kuliah-umum-di-universitas-andalas-kepala-bnptingatkan-ancaman-infiltrasi-ideologi-radikal-terorisme.html. Diakses Tanggal 20 Mei 2019. 
koleganya di berbagai penjara di Indonesia dan berusaha meyakinkan mereka untuk menghentikan aksi-aksi kekerasan. ${ }^{23}$

Program deradikalisasi dengan pendekatan soft dilakukan melalui proses membangun kepercayaan dan moral kepada para terpidana. Salah satu strategi utama untuk program deradikalisasi dengan pendekatan soft ini adalah dengan menyediakan insentif dan menghubungi pihak keluarga terpidana teroris. Satu hal yang penting dicatat adalah bahwa dalam langkah deradikalisasi, khususnya terhadap para narapidana kasus terorisme, pihak berwenang tidak melibatkan secara langsung tokoh agama atau ulama untuk menjadi semacam interlocutor atau mediator dalam membujuk dan mempengaruhi terpidana tersebut, sebab mereka memandang ulama yang selama ini tidak mendukung aksi mereka adalah bagian dari tagut yang menentang Islam dan berada di luar lingkaran mereka. ${ }^{24}$

Strategi soft deradicalization berikutnya adalah dengan menyediakan bantuan finansial selama berada di penjara dan memberikan pelatihan untuk pengembangan skill tertentu untuk persiapan mereka saat kembali bermasyarakat dan bersosialisasi secara normal. Fasilitas lain yang disediakan pihak kepolisian adalah kebebasan pihak keluarga narapidana untuk berkunjung, menyiapkan tiket pulang, menyediakan tempat, makanan, dan penanganan kesehatan yang lebih layak, bahkan jika diperlukan menyiapkan dana untuk kebutuhan pernikahan yang akan diselenggarakan di dalam tahanan.

Langkah di atas memang tidak cukup mudah dilakukan terutama dalam memberikan kontrol saat mereka ada dalam penjara. Lembaga pemasyarakatan dengan berbagai problem yang ada di dalamnya memiliki kapasitas yang terbatas untuk keberhasilan langkah-langkah tersebut. Sebab, tidak mudah menangani para terpidana dan mereka cenderung tidak akan bisa menerima setiap arahan yang berhubungan dengan program deradikalisasi yang sedang dijalankan bagi mereka. Pada saat bersamaan, pihak petugas dari Lembaga Pemasyarakatan juga tidak siap dalam menjalankan program deradikalisasi. ${ }^{25}$

Sementara deradikalisasi sebagai program penanganan untuk upaya menetralkan pemikiran-pemikiran mereka yang telah terpapar

\footnotetext{
${ }^{23}$ Milda Istiqomah, "De-radicalization Program in Indonesian Prisons: Reformation on the Correctional Institution," dalam Proceedings of the First Australian Counter Terrorism Conference, 5-7 Desember 2013, 30

${ }^{24}$ International Crisis Group, “'Deradicalization' and Indonesian Prisons," dalam Crisis Group Asia Report, no. 142, 2007.

25 Istiqomah, "De-radicalization Program," 31
} 
radikalisme, kontra-radikalisasi adalah usaha untuk mencegah kelompok masyarakat dari pengaruh paham radikalisme tanpa menggunakan paksaan yang dapat melahirkan kontra-produktif. Tujuan utama upaya kontra-radikalisasi adalah penguatan masyarakat dan memberdayakan mereka dari pengaruh-pengaruh paham radikal. ${ }^{26}$

BNPT telah melakukan langkah kontra radikalisasi secara langsung kepada masyarakat maupun melalui media sosial melalui berbagai program. ${ }^{27}$ Salah satu program yang sedang dilakukan adalah dengan cara mengajak anak muda untuk menjadi duta dunia maya. Mereka bertugas untuk menyebarkan pesan-pesan damai dan positif melalui media sosial dengan bahasa anak muda. Selain itu, BNPT juga telah membentuk FKPT (Forum Koordinasi Pencegahan Terorisme) di berbagai daerah. ${ }^{28}$ Di sisi lain, BNPT bersinergi dengan lembaga dan kementerian terkait, pemerintah daerah, pimpinan daerah, dan masyarakat, serta selalu mengadakan berbagai kerjasama dengan beberapa pihak, baik organisasi maupun lembaga pendidikan.

Keberhasilan program kontra-radikalisasi akan maksimal jika berbagai pihak dari seluruh elemen masyarakat berperan aktif dalam membendung radikalisme dan memberikan kontrol terhadap merebaknya upaya-upaya radikalisasi di berbagai tempat yang potensial. Selama ini, telah dilakukan langkah-langkah nyata di berbagai tempat seperti pesantren, ${ }^{29}$ kampus dan sekolah, ${ }^{30}$ forumforum pengajian, dan lembaga pendidikan lainnya. Karena itu, pemahaman tentang moderasi Islam menjadi kurikulum yang tepat sebagai salah satu langkah nyata. Menurut Nur Syam, ${ }^{31}$ untuk melahirkan cara pandang yang tepat sekaligus menghilangkan radikalisme maka perlu belajar dan menerapkan ideologi atau prinsip dasar Ahlus Sunnah wal Jamaah atau NU dengan empat ciri berikut: pertama, tawassut (moderat), yakni sikap pertengahan yang tidak

\footnotetext{
${ }^{26}$ Schmid, Radicalisation, 51-52

27 Tim BNPT, "Cegah Paham Radikal Terorisme dengan Melek Media," dalam https://www.bnpt.go.id/cegah-paham-radikal-terorisme-dengan-melek-media.html. Diakses 5 Mei 2019,

28 Tim BNPT, "Kepala BNPT Berikan Paparan dalam Rapat Pleno ke-25 MUI," dalam https://www.bnpt.go.id/kepala-bnpt-berikan-paparan-dalam-rapat-pleno-ke25-mui.html. Diakses Tanggal 22 Juli 2018.

${ }^{29}$ Darmaji, "Pondok Pesantren"; Kusmanto, dkk., "Dialektika Radikalisme," 40-41.

30 Zulfa Sesmiarni, "Membendung Radikalisme dalam Dunia Pendidikan melalui Pendekata Brain Based Learning," dalam Jurnal Kalam, vol. 9, no. 2 (2015).

${ }^{31}$ Nur Syam, Tantangan Multikulturalisme Indonesia (Yogyakarta: Kanisius, 2009), 176.
} 
ekstrem kanan maupun kiri. Prinsip ini mengajarkan bahwa dalam menjalani kehidupan harus memperhatikan aspek duniawi dan ukhrawi secara seimbang. Kedua, tawäąun (seimbang), sebagai sikap seimbang dalam segala hal, termasuk dalam penggunaan dalil naqli dan 'aqli. Ketiga, ítidall (tegak lurus), sebagai sikap lurus, tegak bersikap adil. Keempat, tasämub̧ (toleransi), yakni menghargai perbedaan dan menghormati prinsip hidup pihak lain yang tidak sama.

\section{PSQ dan Tafsir Moderat}

PSQ didirikan pada tahun 2004 pasca munculnya berbagai aksi terorisme dan merebaknya paham-paham radikal oleh sebagian kelompok beragama. Lembaga ini memiliki visi untuk mewujudkan nilai-nilai Alquran di tengah masyarakat yang pluralistik. Visi tersebut secara eksplisit memang tidak menjelaskan tentang moderasi, namun kata "pluralistik" mengarah pada makna tersebut. Hal itu dipertegas dalam keterangan Muchlis Hanafi, sebagai direktur PSQ penerus Prof Quraish Shihab, bahwa sejak awal lembaga ini memang didirikan untuk membumikan tafsir moderat dan untuk proses kontraradikalisasi sebagai respon atas maraknya paham radikal yang mengatasnamakan ajaran Alquran dan Hadis. ${ }^{32}$

Fokus PSQ adalah meneruskan risalah Nabi yang termaktub dalam QS. al-Jumu'ah [62]: 2. Ayat tersebut merupakan ringkasan tentang tata cara berinteraksi dengan Alquran dalam tiga hal: (1) berinterasksi secara tilawatan, hif z̧an, dan istimäan; (2) menafsirkan dan memahaminya; dan (3) mengamalkan dan mendakwahkan kepada masyarakat. Bentuk interaksi yang pertama dan ketiga sudah dilaksanakan dengan baik di kalangan masyarakat. Sudah banyak dijumpai berbagai metode cepat membaca dan menghafal Alquran, termasuk juga aplikasi-aplikasi Alquran untuk mempermudah kaum Muslim berinteraksi dengan kitab sucinya. Begitu pula dengan poin ketiga, yakni Alquran diamalkan dan didakwahkan. Mengamalkan Alquran dan mendakwahkannya telah banyak dilakukan. Bahkan, orang yang tidak cakap dalam bidang tafsir Alquran atau minim pemahaman keagamaannya bisa percaya diri dalam mendakwahkan Alquran dan nilai-nilai Islam. Karena itu, PSQ berupaya melakukan langkah-langkah untuk poin kedua di atas, yakni pemahaman dan penafsiran Alquran. Bagi PSQ, upaya tersebut

32 Wawancara dengan Muchlis Hanafi, Direktur PSQ, di Hotel Shakti Bandung, Tanggal 3 Oktober 2018. 
tergolong masih jarang di masyarakat. Tidak sedikit masyarakat yang membaca dan mengamalkan Alquran, namun mereka belum tentu memiliki kemampuan memahami dengan baik, apalagi menafsirkan ayat-ayat Alquran.

Untuk alasan di atas, PSQ menempuh beberapa langkah nyata. Pertama, melakukan kerjasama dengan berbagai lembaga studi Alquran baik di dalam maupun luar negeri. Di dalam negeri kerjasama sudah dijalin dengan berbagai kampus melalui kegiatan-kegiatan ilmiah seperti seminar, halaqah maupun pelatihan. Kerjasama dengan kampus-kampus dilaksanakan dalam bentuk seminar, pelatihan, dan kegiatan Daurah Tafsir. Program kegiatan yang disebut terakhir pada umumnya dikemas dalam kegiatan PPL (Praktik Pengalaman Lapangan) mahasiswa dari berbagai perguruan tinggi Islam. ${ }^{33}$ Saat ini kerjasama dengan beberapa kampus Islam lebih banyak untuk pelaksanaan Praktik Pengalaman Lapangan atau Praktik Pengalaman Mahasiswa (PPM). Perguruan tinggi yang telah bekerjasama dengan PSQ antara lain: IAIN Salatiga, IAIN Tulung Agung, IAIN Cirebon, IAIN Ternate, dan UIN Syarif Hidayatullah Jakarta. ${ }^{34}$ Kerjasasama lainnya dilakukan dengan berbagai media baik televisi maupun radio yang dimaksudkan untuk menyebarkan nilai-nilai Alquran melalui ceramah dan talkshow virtual. Para pakar dari PSQ selama ini telah mengisi berbagai acara di berbagai media elektronik tersebut.

Kedua, program pendidikan tafsir, berupa Program PKM (Pendidikan Kader Mufasir), PPT (Pendidikan Pasca Tahfidz) dan Daurah Bidayatul Mufassir. PKM diselenggarakan dalam waktu satu semester khusus bagi mahasiswa pascasarjana yang sedang menyelesaikan riset tesis dan disertasi bidang Alquran dan tafsir. Melalui program ini para lulusan dari program pendidikan kader ini dimaksudkan agar mereka memiliki kompetensi dalam memahami tafsir Alquran. Tujuan tersebut cukup realistis meskipun durasi pelaksanaan kaderisasi hanya 6 bulan, sebab para kader adalah calon magister dan calon doktor dalam bidang tafsir dan sedang melakukan riset dalam bidang tafsir Alquran.

Program lain yang menjadi andalan PSQ adalah Pendidikan Pasca Tahfidz. Pendidikan ini dikhususkan bagi lulusan tahfiz yang telah

\footnotetext{
33 Wawancara dengan Ahmad Zayadi, Manajer Program PSQ, di Pesantren Bayt Alquran Tangerang Selatan, tanggal 23 April 2018.

34 Wawancara dengan Ahmad Zayadi, di Pesantren Bayt Alquran Tangerang Selatan, tanggal 3 Oktober 2018.
} 
memiliki hafalan 30 juz yang berasal dari berbagai pesantren di Indonesia. Pelaksanaan program Pesantren pasca-Tahfiz berpusat di Pesantren Bayt Al-Qur'an yang masih satu atap di bawah Yayasan Lentera. Program ini dilaksanakan secara periodik setiap enam bulan. Para santri dibekali dengan imu-ilmu Alquran dan tafsir untuk menjalankan visi PSQ sendiri.

Selain itu, program Daurah Bidayatul Mufasir juga menjadi bagian dari program pendidikan tafsir untuk kalangan mahasiswa Strata-1 program studi Ilmu Alquran dan Tafsir dari berbagai perguruan tinggi di Indonesia. PSQ secara bertahap menerima mahasiswa dari berbagai perguruan tinggi Islam di Indonesia seperti IAIN Pekalongan, IAIN Cirebon, IAIN Ternate, IAIN Tulung Agung, IAIN Surakarta, IAIN Salatiga, IAIN Samarinda dan beberapa kampus Islam lainnya.

Kegiatan bagi mahasiswa tersebut diformat dalam bentuk Daurah Tafsir yang dilaksanakan dalam durasi waktu antara satu hingga dua minggu. Dalam waktu tersebut para mahasiswa mendapat bimbingan langsung dari para dewan pakar Pusat Studi Al-Qur'an mengenai ilmu tafsir Alquran, kaidah kebahasaan Alquran, ușül al-tafsì, termasuk maqāsid al-Qur'ān. Metode yang disampaikan adalah metode klasikal dan tanya jawab. Kurikulum tersebut dilengkapi dengan materi penguatan keterampilan seperti public speaking, penelusuran literatur tafsir berbasis ICT, praktikum tafsir (tadrib wa tahfig), rihlah Qur'aniyah, dan program kepesantrenan. Materi praktikum ini mengacu pada tiga keterampilan yang diberikan kepada peserta mahasiswa, yaitu keterampian dalam menjelaskan tafsir (skills of explaining tafsir), keterampilan menjawab isu-isu terkini dengan pendekatan tafsir (skills of respond) dan keterampilan menulis tafsir (skills of writing tafsir). Skills of explaining tafsir dilaksanakan dalam bentuk ceramah di hadapan jemaah salat wajib dan ceramah audio visual. Skills of writing tafsir dilaksanakan dalam bentuk penugasan menulis artikel seputar tafsir. Selain itu, peserta Daurah Tafsir juga mendapatkan bimbingan membaca Alquran dengan baik dan benar serta tahfiz Alquran. Setiap peserta memiliki kesempatan untuk melaksanakan tugas keterampilan tersebut. ${ }^{35}$

PSQ juga memiliki program pendidikan dalam bentuk ToT (Training of Trainer). Kegiatan ini bertujuan untuk membekali para

\footnotetext{
35 Wawancara dengan Ahmad Zayadi, di Pesantren Bayt Alquran Tangerang Selatan, tanggal 10 Maret 2018.
} 
peserta dari kalangan dai/penyuluh agama, guru agama Islam maupun dosen pengajar tafsir Alquran dengan wawasan Islam yang moderat dan toleran. Materi utama yang diberikan dalam bentuk modul meliputi materi moderasi Islam, toleransi dalam Islam dan kaidahkaidah penafsiran Alquran dan bagaimana berinteraksi dengan Alquran dan sunah. ${ }^{36}$ Melalui pembekalan ini, para peserta diharapkan mampu menyebarkan wajah Islam yang ramah kepada para jemaah, mahasiswa dan murid binaan mereka. Langkah itu sekaligus menjadi bagian dari upaya kontra-radikalisasi di tengah masyarakat melalui kegiatan pembelajaran maupun pengajian yang dilaksanakan oleh mereka baik dai, guru maupun dosen.

Ketiga, asistensi khutbah Jumat. Lokasi pelaksanaan program ini salah satunya dipusatkan di Bellagio Mall Kuningan Jakarta. Pelaksanaan shalat Jumat ini dilaksanakan secara paket oleh PSQ: imam dan khatib Jumat diisi oleh dewan pakar PSQ; untuk muazin, bilal, dan pengisi tilawah Alquran adalah santri Pesantren Bayt AlQur'an di bawah yayasan yang sama. Selain di tempat tersebut, PSQ juga melakukan kerjasama dengan masjid lain di sekitar JakartaTangerang untuk pelaksanaan khutbah Jumat.

Keempat, pengaiian halaqah tafsir. Secara historis, pengajian halaqah tafsir ini dilaksanakan secara bersamaan dengan diresmikannya Lembaga Pusat Studi Alquran pada tahun 2004. Pada lima tahun pertama pengajian ini ditempatkan di kantor PSQ, namun sejak tahun 2009 pelaksanaannya dipindah ke Pesantren Bayt AlQur'an Pondok Cabe Tangerang. Pengajian ini dihadiri secara terbuka oleh masyarakat umum dari berbagai elemen masyarakat di seputar Jabodetabek. Jemaah yang hadir pada setiap kegiatan berkisar antara 70 sampai 100 orang. Kegiatan ini diawali dengan belajar mengaji dan membaca Alquran secara tartil yang dipandu oleh santri hafiz di Pesantren Bayt Al-Qur'an.

Halaqah tafsir adalah pengajian untuk umum yang diselenggarakan setiap hari Rabu di Pondok Pesantren Pasca-Tahfiz Bayt Al-Qur'an Pondok Cabe. Materi pengajian diberikan dalam bentuk ceramah dan tanya jawab, menggunakan dua model: tematik dan tahliliz. Pada model tematik, pembahasan yang diangkat berkaitan dengan isu-isu problematika sosial keagamaan yang berkembang di masyarakat dalam perspektif Alquran. Misalnya, korupsi dalam

36 Tim PSQ, "Halaqah Tafsir," dalam https://psq.or.id/program-2/. Diakses Tanggal 4 Juni 2019. 
perspektif Alquran dan peran perempuan dalam keluarga. Sementara pendekatan taḅlili digunakan dengan mengupas ayat demi ayat, misalnya mengupas surah al-Anfāl [8]: 27-28. ${ }^{37}$ Tema pengajian lainnya yang diformat dalam pendekatan taḅliti adalah tentang surah Yūnus tentang: konsep ummah wähidah (QS. Yūnus [10]: 14-23); konsep berbuat baik (QS. Yūnus [10]: 24-30), bukti kekuasaan Allah terhadap kaum Musyrik (QS. Yūnus [10]: 31-36) dan seterusnya. Sementara pendekatan tematik mengangkat tema seperti: (1) Berbisnis dalam terminologi Alquran; (2) Sistem ekonomi Islam dalam perspektif Alquran; (3) Harta dalam Alquran; (4) Konsep Maslahat menurut Alquran; (5) Zikir dan wirid dampaknya dalam kehidupan; (6) Doa dalam kehidupan; (7) Moderasi ajaran Islam; (8) Keragaman dan kerukunan menurut Alquran. Selain tema tersebut, tema 'ulum alQur'àn juga disampaikan, seperti metode dan prinsip menafsirkan Alquran, wahyu Ilahi dan otentisitas (keaslian) Alquran, bahasa Alquran, serta tema menyikapi kesalahpahaman dan penyimpangan dalam penafsiran Alquran. Di luar tema-tema tersebut, sesekali tersajikan pula tema-tema yang mengungkap kandungan buku yang telah dikarang oleh beberapa pakar. ${ }^{38}$

Kelima, program 'Living Qur'an', yakni sebuah program berkala yang menekankan pada kurikulum belajar Alquran untuk anak usia sekolah. Program ini merupakan kurikulum pendidikan agama Islam yang dikemas dalam bentuk kegiatan yang menyenangkan bagi anak remaja dan relevan dengan keseharian mereka. Program ini dilaksanakan dalam rangkaian kegiatan kunjungan ke beberapa kota. Kota Bandung adalah tempat pertama dari kegiatan ini yang mengusung tema: "Hidup Bersama Alquran Sepanjang Sejarah Indonesia”, yang dilaksanakan pada 24-25 Februari 2017. Rangkaian kegiatan yang dilaksanakan adalah 'ngobrol publik' dan 'pameran publik'. Pada kegiatan ngobrol publik ini, setelah narasumber dari pihak PSQ menyampaikan materinya, dibuka dialog dengan para peserta yang tak lain dari kalangan remaja. Pembahasan pertama dijelaskan tentang maksud dari ungkapan bahwa Islam adalah agama yang rahmat bagi semua alam yang merujuk pada QS. al-Anbiyā' [21]: 107. Materi kedua yang disampaikan dalam acara Living Qur'an

37 Tim PSQ, "Halaqah Tafsir," dalam http://psq.or.id/wp-content/uploads /2013/02/ Profile-Halaqah-Tafsir-2013. Diakses Tanggal 30 Juli 2018.

38 Tim PSQ, "Halaqah Tafsir," dalam http://psq.or.id/wp-content /uploads/2013/02/Profile-Halaqah-Tafsir-2013. Diakses 30 Juli 2018. 
tersebut adalah mengenai berita palsu atau hoaks. Pembahasan mengenai materi ini merujuk pada ayat Alquran yang mengajarkan tentang pola atau tata cara berkomunikas dengan prinsip tabayyun. ${ }^{39}$

Kota lainnya adalah Ambon yang pernah diselenggarakan bersamaan dengan Pesta Pendidikan 2017 yang bertepatan pada tanggal 17-18 Maret. Rangkaian festival publik di Kota Ambon ini melibatkan beberapa sekolah, yaitu SMA Xaverius, SMA 1, SMA 2, SMA PGRI 1, SMA Kristen YPKPM, SMK 7 dan SDI Al-Fatah. Kegiatan dilaksanakan dalam bentuk ngobrol publik berupa diskusi dan lokakarya dari berbagai komunitas. ${ }^{40}$ Selain itu, kegiatan Living Quran juga dilaksanakan di beberapa tempat, yaitu Yogyakarta, Makassar, dan Jakarta.

\section{PSQ dan Program Kontra-Radikalisasi}

Radikalisasi atas nama agama selama ini banyak dilakukan secara masif dan strategis di tengah masyarakat. Melalui lembaga pendidikan formal maupun non-formal, kelompok radikal menanamkan ideologi keagamaan yang mengarah ke paham radikalisme. Langkah semacam ini pun dilakukan PSQ untuk mengimbangi gerakan mereka. PSQ berupaya melakukan counter atas pemahaman keagamaan yang banyak menyerukan ajaran-ajaran yang bertentangan dengan prinsip dasar Islam dan nilai-nilai kehidupan berbangsa dan bernegara. Berbagai program kegiatan telah dilakukan PSQ terhadap berbagai lapisan masyarakat baik siswa sekolah, mahasiswa dari jenjang sarjana hingga pasca-sarjana, para dai, penyuluh agama, guru tafsir hingga masyarakat umum. Secara umum, langkah kontra-radikalisasi yang ditempuh PSQ melalui dua program utama berikut:

\section{Program Kaderisasi}

Program ini dicanangkan untuk mencetak kader yang akan membumikan dan mensosialisasikan Islam moderat melalui penafsiran yang memadai dan komprehensif berdasarkan kaidahkaidah tafsir dan kontekstual dalam konteks keindonesiaan. Hal ini sesuai dengan salah satu misi PSQ, yaitu melahirkan kader-kader

\footnotetext{
39 "Tetes Embun Penyegar dari Kegiatan Living Quran di Pekan Bandung," dalam https:/ / alifmagz.com/whats-on/tetes-embun-penyegar-dari-kegiatan-living-qurandi-pekan-2017-bandung/. Diakses tanggal 19 Agustus 2018.

40 "Living Qur'an Ramaikan Pesta Pendidikan dalam Festival Publik di Ambon," dalam https://alifmagz.com/whats-on/living-quran-ramaikan-pesta-pendidikandalam-festival-publik-di-ambon. Diakses Tanggal 19 Agustus 2018.
} 
mufasir yang profesional. Kader yang diharapkan lahir adalah mereka yang mampu berinteraksi dengan Alquran baik tiläwatan, bif zan maupun istimäan. Tidak hanya itu, melalui kaderisasi diharapkan mereka mampu memahami dan menafsirkan Alquran, kemudian mendakwahkan dan mengamalkannya dalam kehidupan sehari-hari.

Sasaran program ini adalah elemen masyarakat intelektual dari berbagai level mulai dari mahasiswa, dosen, santri penghafal Alquran hingga dai, guru dan penyuluh agama. Beberapa program yang telah dijalankan selama ini adalah: (1) Pendidikan Kader Mufasir (PKM); (2) Pesantren Pasca-Tahfidz (PPT); dan (3) Daurah Bidayatul Mufassir. PKM (Pendidikan Kader Mufasir) adalah program kaderisasi bagi mereka yang telah memiliki dasar pemahaman ilmu tafsir. Sebagian besar dari mereka adalah para penghafal Alquran, dosen, sekaligus penceramah. Karena itu, para alumni dari program ini dituntut untuk menyampaikan nilai-nilai moderasi Islam kepada komunitasnya masing-masing.

Pesantren Pasca-Tahfidz (PPT) juga menjadi program kaderisasi bagi para santri yang telah menghafal Alquran 30 juz. Dengan bekal hafalan sempurna, mereka memiliki modal yang cukup besar untuk mendidik masyarakat yang tidak hanya membaca Alquran, namun juga merangkap untuk menerangkan tafsir atas kitab suci dalam bingkai moderasi Islam.

Di tingkat mahasiswa, program Daurah Bidayatul Mufassir menjadi program kegiatan yang dimaksudkan untuk memberi bekal kepada generasi muda Islam tentang pemahaman nilai-nilai Alquran yang moderat dan toleran. Bekal pemahaman tersebut akan menjadi penyeimbang atas maraknya radikalisasi di berbagai kampus belakangan ini. Durasi waktu yang sangat minim bagi peserta program ini memang tidak ideal untuk menanamkan bekal pengetahuan yang cukup bagi mereka. Namun, kerjasama yang berkelanjutan dengan kampus atau program studi para mahasiswa menjadi langkah berjenjang pula dalam upaya menyebarluaskan pemahaman tafsir moderat. Selain itu, program To'T (Training of Trainer) juga menjadi program pembinaan para tenaga profesional baik dai maupun penyuluh agama, guru agama Islam maupun dosen pengajar tafsir di beberapa daerah. Program kegiatan ini bersifat insidental dan hanya dilaksanakan dalam waktu singkat di beberapa kota di Indonesia. Namun, materi pelatihan akan memberi bekal yang cukup bagi para 
peserta mengenai wawasan keislaman yang moderat dan toleran serta kaidah-kaidah penafsiran Alquran.

PSQ sebagai lembaga kaderisasi calon mufasir Alquran bermaksud agar para kader mampu memahami dan menafsirkan Alquran dengan baik, dengan prinsip keseimbangan antara literaltekstual dan liberal, dalam arti tidak tekstual dan tidak pula bebas atau liberal. Di poin inilah PSQ hendak menegaskan posisinya sebagai pusat kajian tafsir Alquran yang mengedepankan moderatisme dalam konteks kehidupan berbangsa dan bernegara.

\section{Program Pembinaan Langsung}

Program ini dilakukan PSQ ke berbagai tempat di tengah masyarakat, bahkan di tempat yang berpotensi terpapar radikalisme. Pertama, asistensi khutbah di beberapa masjid yang dilakukan PSQ menjadi langkah riil dalam upaya kontra-radikalisasi. Masjid sebagai tempat pelaksanaan ibadah umat Islam juga menjadi tempat untuk menyampaikan pesan-pesan keagamaan kepada masyarakat. Setiap hari Jumat, khutbah disampaikan kepada kaum muslimin. "Rumah Allah" ini adalah miliki semua umat Islam. Ia berfungsi secara terbuka bagi umat dengan mazhab apapun. Namun, belakangan masjid seringkali menjadi tempat eksklusif bagi kelompok atau ideologi tertentu. Fungsi sebagian masjid mengalami pergeseran. Bahkan rumah ibadah telah menjadi tempat proses kaderisasi suatu kelompok atau ideologisasi paham keagamaan tertentu, termasuk kaderisasi kelompok radikal dan ideologisasi paham radikalisme. ${ }^{41}$

PSQ menyadari fenomena ideologisasi paham radikal melalui media Masjid. Karena itu, PSQ mengambil langkah kongkret untuk melakukan kontra-radikalisasi melalui asistensi khutbah Jumat, khususnya di sekitar wilayah Jakarta. Jakarta merupakan wilayah ibu kota yang belakangan cukup rentan mendapatkan "serangan" paham radikalisme salah satunya melalui masjid. Pihak BNPT pernah merilis bahwa radikalisme di masjid Jakarta sudah terjadi sejak 2012. ${ }^{42}$ Bahkan Badan Nasional Penanggulangan Terorisme ini mencatat, terdapat 40

\footnotetext{
41 Sunaryo, "Masjid dan Ideologisasi," 228.

42 Rahmat Nur Hakim, "BNPT Sebut Ada Masjid Terpapar Radikalisme Sejak 2012” dalam https://nasional.kompas.com/read/2018/06/07/13221261/bnptsebut-ada-masjid-terpapar-radikalisme-sejak-2012. Diakses tanggal 6 Oktober 2018.
} 
masjid yang mengajarkan paham radikalisme di pusat ibu kota tersebut. ${ }^{43}$

Tema yang diusung dalam khutbah selalu berkaitan dengan kehidupan masyarakat modern termasuk mengenai Islam moderat, seperti ber-Islam dan ber-Indonesia, Islam sebagai rahmat, toleransi dan perdamaian dalam Islam, menebar kebaikan dengan sesama, persaudaraan dan persatuan harus berlandaskan Alquran, Islam khayr ummah di tengah masyarakat, mensyukuri kemerdekaan, menjaga perdamaian antar umat beragama, agama untuk kemanusiaan, lakum dinukum wa liy din. Dari beberapa tema tersebut tampak sekali upaya PSQ untuk menebarkan ajaran-ajaran moderat dalam kehidupan bermasyarakat, berbangsa dan bernegara.

Kegiatan asistensi masjid ini bersentuhan langsung kepada masyarakat. Tujuannya untuk mengimbangi maraknya penceramah atau khatib jumat yang menyampaikan materi khutbah yang tidak ramah bagi kehidupan berbangsa dan bernegara. Muatan-muatan ceramah di berbagai khutbah Jumat banyak disampaikan oleh kalangan yang memiliki pemahaman radikal dan kaku terhadap teksteks agama. Masjid dinilai cukup efektif untuk melakukan ideologisasi paham radikal kepada masyarakat karena khutbah dan ceramah yang disampaikan di tempat ini selalu melibatkan jemaah dalam jumlah yang besar. Maka, untuk memberikan paham "tandingan" kepada masyarakat harus pula berangkat dari tempat yang sama. ${ }^{44}$ Jika masjid menjadi tempat penyebaran paham radikal, maka masjid pula yang harus dijadikan media untuk menyebarkan paham moderat.

Kedua, Pengajian Halaqah Tafsir. Pemahaman radikalisme juga sering disampaikan melalui pengajian. Indonesia merupakan negara dengan mayoritas Muslim terbesar di dunia dan di negeri ini pemeluk Islam sangat dominan secara kuantitas. Salah satu ciri khas dari keberagamaan orang Islam di Indonesia adalah tradisi pengajian keagamaan. Dalam kegiatan inilah ajaran-ajaran agama disampaikan kepada para jemaah yang hadir. Ideologisasi keislaman sangat tampak melalui orasi keagamaan melalui pengajian tersebut. Artinya, seorang penceramah pada sebuah pengajian akan menyampaikan materi-

43 "40 Masjid Paham Radikal di Jakarta Terdeteksi sejak 2012," dalam https://www.viva.co.id/berita/metro/1043645-40-masjid-paham-radikal-di-jakartaterdeteksi-sejak-2012. Diakses tanggal 6 Oktober 2018.

${ }^{44}$ Donatella, Della Porta, \& LaFree, G.. "Guest editorial: Processes of radicalization and de-radicalization," dalam International Journal of Conflict and Violence (IJCV), vol. 6, no. 1 (2012), 8. 
materi yang sesuai dengan pola pemikiran keagamaannya. Melihat keragaman masyarakat Indonesia, maka seharusnya ceramah yang disampaikan tidak menyinggung perasaan komunitas lain baik menyangkut perbedaan agama, suku, politik, budaya dan tradisi masyarakat. Seorang penceramah seharusnya menyampaikan materimateri yang menyejukkan bagi para jemaah. Akan tetapi, apa yang terjadi di lapangan cenderung menunjukkan sebaliknya. Sebagian penceramah memberikan "serangan" kepada komunitas lain dengan cara menyalahkan hingga bernada takfiri (mengkafirkan kelompok lain yang tidak sejalan dengan pemikiran keagamaannya). Sebagian yang lain justru mengajak jemaah untuk menentang prinsip dasar bernegara.

PSQ sebagai pusat mengaji tafsir Alquran juga tidak abai menyapa masyarakat melalui pengajian umum. Pengajian yang dilaksanakan PSQ ini disebut Pengajian Halaqah Tafsir (HT). Pengajian ini merupakan kegiatan rutin setiap hari rabu. Kegiatan ini sudah berjalan sejak awal berdirinya PSQ. Pengajian ini adalah media belajar masyarakat yang terbuka untuk umum. Kegiatan ini juga bagian dari upaya PSQ berinteraksi dengan masyarakat dalam rangka membumikan Alquran. Melalui kegiatan ini masyarakat tidak hanya mendapatkan bekal pemahaman seputar kandungan ayat-ayat Alquran. Melalui kegiatan ini mereka juga dapat belajar membaca Alquran di bawah bimbingan langsung dari santri tahfiz.

Melalui kegiatan Halaqah Tafsir, masyarakat diperkenalkan dengan pesan-pesan Alquran. Pesan moderasi sangat tampak dari tema dan materi yang disampaikan dalam setiap minggunya. Misalnya, konsep ummah wähidah (QS. Yūnus [10]: 14-23); konsep berbuat baik (QS. Yūnus [10]: 24-30), moderasi ajaran Islam; dan keragaman dan kerukunan menurut Alquran. ${ }^{45}$ Kegiatan halaqah atau pengajian rutin ini menjadi media PSQ untuk mengenalkan umat kepada ajaran-ajaran moderat, ramah dan toleran dalam konteks kehidupan berbangsa, bernegara dan bermasyarakat yang tidak lepas dari budaya Indonesia, sehingga jemaah terhindar dari pemahaman keagamaan yang kaku, ekstrem dan radikal.

Ketiga, Program Living Quran. PSQ juga berusaha menyebarluaskan nilai-nilai Alquran kepada masyarakat kalangan remaja. Living Quran adalah pogram PSQ yang sasarannya adalah

45 Tim PSQ, "Halaqah Tafsir", dalam https://psq.or.id/program-2/halaqah-tafsir2/. Diakses Tanggal 30 Juli 2018. 
siswa sekolah. Tujuan dari program ini adalah untuk memperkenalkan kepada anak remaja bahwa Islam adalah agama yang ramah bagi semua alam. Dari tema yang dibawakan pada setiap penyelenggaraan kegiatan Living Quran di beberapa kota di Indonesia cukup tampak penekanan terhadap tujuan tersebut. Misalnya, tema tentang berita palsu atau hoaks yang disampaikan melalui rujukan ayat Alquran tentang ajaran tata cara berkomunikasi dengan prinsip tabayun. Program ini telah dilaksanakan di beberapa kota seperti Bandung, Ambon, Yogyakarta, Makasar dan Jakarta. Berbagai sekolah di kota tersebut telah terlibat dalam program kegiatan Living Quran ini. Tidak hanya siswa sekolah Islam, siswa sekolah non-Muslim juga menjadi bagian dari kepesertaan kegiatan ini, seperti SMA Kristen YPKPM, Ambon.

Berbagai program kegiatan PSQ dilaksanakan dengan baik karena jaringan kerjasama dengan berbagai instansi dan lembaga baik LSM maupun lembaga pendidikan sekolah dan perguruan tinggi. Kerjasama dengan berbagai kampus di Indonesia akan semakin memperkuat posisi PSQ dalam menyuarakan pemahaman Islam moderat. Namun demikian, PSQ tidak melakukan kerjasama dengan lembaga pemerintah termasuk BNPT (Badan Nasional Penanggulangan Terorisme). Menurut Muchlis Hanafi, selaku direktur saat ini, PSQ pernah melakukan kerjasama dengan pihak lembaga pemerintah untuk melakukan program deradikalisasi atau kontra-radikalisasi, namun kerjasama tersebut hanya berjalan dalam waktu yang singkat dan belum pernah melakukan kegiatan-kegiatan tertentu. Alasan yang disampaikan Hanafi adalah untuk menjaga kemandirian lembaga dan agar tidak timbul kecurigaan dari masyarakat mengenai PSQ sendiri dalam menjalankan program-programnya. ${ }^{46}$ Langkah ini merupakan bagian dari sikap strategis PSQ agar bisa diterima oleh kelompok Muslim yang selama ini cenderung memiliki pemahaman keagamaan yang ekstrem dan eksklusif, sebab mereka pada umumnya antipati terhadap pemerintah yang mereka anggap tidak mampu memberikan kesejahteraan bagi umat Islam pada umumnya.

Program-program PSQ dalam meneguhkan moderasi Islam tidak hanya untuk kaum laki-laki. Kaum perempuan juga banyak terlibat dalam berbagai program kegiatan tersebut, kecuali dalam konteks asistensi masjid yang hanya khusus bagi jemaah laki-laki dan pesantren

\footnotetext{
46 Wawancara dengan Muchlis Hanafi di Hotel Shakti Bandung, Tanggal 3 Oktober 2018.
} 
pasca-tahfidz. Keterlibatan kaum perempuan, baik di tingkat sekolah, mahasiswi, dosen, guru, maupun jemaah pengajian menjadi poin penting dalam upaya moderasi Islam. Sebab, paham radikalisme yang terjadi tidak hanya melibatkan kaum laki-laki. Sebagian aksi terorisme beberapa waktu terakhir juga dilakukan oleh perempuan remaja, seperti yang terjadi di Surabaya. Karena itu, sasaran program PSQ ke berbagai sekolah dan kampus tanpa memilih jenis kelamin merupakan langkah tepat.

Upaya PSQ dalam menyebarluaskan Islam moderat mudah diterima di tengah masyarakat karena ketokohan pendiri sekaligus tokoh utamanya, yaitu Quraish Shihab. Meskipun ia sering diserang dengan fitnah Shi'isme yang disematkan kepadanya, namun sebagian insan akademik masih memandangnya sebagai intelektual Muslim Indonesia yang sangat alim dan moderat. Hal itu telah lama dibuktikannya melalui pelbagai ceramah dan tulisannya. Produktifitasnya membuktikan kapabilitas dirinya sebagai tokoh mufasir zaman ini. Karya tafsir monumentalnya, Tafsir al-Mishbah, menjadi bukti peneguhan atas otoritas tersebut. Quraish Shihab telah memberikan corak penafsiran yang moderat dengan tetap mengacu pada kaidah-kaidah tafsir. Karya-karya yang lain memperkuat posisi Quraish Shihab yang juga didukung dengan ceramah-ceramahnya di berbagai forum seminar maupun media televisi. Melalui berbagai forum dan media tersebut Quraish Shihab selalu konsisten dalam upaya penyebaran gagasan Islam moderat.

Hal lain yang menjadi alasan adalah tokoh-tokoh yang akrab dengannya, seperti Gus Mus (Kiai Musthafa Bisri), Nazaruddin Umar (juga sebagai tokoh PSQ), ${ }^{47}$ dan Muchlis Hanafi (junior sekaligus tokoh produktif PSQ). ${ }^{48}$ Mereka adalah para tokoh yang selama ini sangat serius menyuarakan Islam santun, moderat dan toleran melalui tulisan dan ceramahnya. Hal itu sekaligus menjadi kekuatan PSQ untuk terus mengawal tafsir moderat untuk membentengi umat Islam dari virus radikalisme agama yang masih menggurita di negeri ini.

Sejak awal berdirinya, lebih dari seribu alumni yang pernah mengikuti berbagai program yang dilaksanakan PSQ. Mereka tersebar di berbagai daerah di Indonesia. Jumlah tersebut berasal dari berbagai

\footnotetext{
47 Nasaruddin Umar, Islam Fungsional, Revitalisasi dan Reaktualisasi Nilai-nilai Keislaman (Jakarta: PT. Gramedia, 2014), 78-80.

48 Muchlis Muhammad Hanafi, "Hubungan Antar agama," dalam Subuf Jurnal Pengkajian Alquran dan Budaya, vol. 1, no. 1 (2008), 35-41.
} 
program kaderisasi penguatan moderasi tafsir Alquran, tidak termasuk program lainnya. Namun, efektivitas penguatan moderasi Islam sebagai bagian dari upaya kontra-radikalisasi yang dilakukan PSQ selama ini kurang maksimal. Jaringan kerjasama dengan para alumni belum terlaksana secara serius. Padahal para alumni dari program kaderisasi PSQ tersebar di berbagai daerah di Indonesia. Memperkuat jaringan dengan mereka tentu akan semakin memperkuat penyebaran moderasi Islam yang tidak hanya melalui pemahaman namun juga dengan perilaku di masyarakat.

\section{Kesimpulan}

Upaya diseminasi tafsir moderat yang dilakukan PSQ menjadi langkah nyata kontra-radikalisasi di tengah masyarakat. Kontraradikalisasi telah dilakukan dalam bentuk program kaderisasi penguatan pemahaman ilmu tafsir (Pendidikan Kader Mufasir, Pesantren pasca-Tahfidz, dan Daurah Bidayah Mufassir). Training of Trainer juga dilaksanakan untuk para dai, guru agama Islam atau guru tafsir. Bentuk kontra-radikalisasi lainnya adalah program Living Quran untuk para siswa di beberapa sekolah dan pembinaan langsung ke masyarakat melalui program Asistensi Masjid dan ceramah atau pengajian untuk masyarakat umum. Dengan demikian, kontraradikalisasi yang dilakukan Pusat Studi Al-Qur'an Jakarta dapat menjadi model dalam upaya menyebarkan Islam moderat dalam konteks keindonesiaan.

\section{Daftar Pustaka}

Azra, Azyumardi. "Indonesian Islam, Mainstream Muslims And Politics." Paper dipresentasi pada Konferensi Taiwanese and Indonesian Islamic Leaders Exchange Project, Taipei, 2006. . Islam Reformis: Dinamika Intelektual dan Gerakan. Jakarta: Raja Grafindo Persada, 1999.

Darmaji, Ahmad. "Pondok Pesantren dan Deradikalisasi Islam di Indonesia." Millah Jurnal Studi Agama, vol. XI, No. 1 (2011).

Donatella, Della Porta, \& LaFree, G.. "Guest editorial: Processes of radicalization and de-radicalization." International Journal of Conflict and Violence, vol. 6, no. 1 (2012).

Gilles, Kepel. Jihad: The Trail of Political Islam. London: I.B. Tauris, 2002. Group, International Crisis, “'Deradicalization' and Indonesian Prisons.” Crisis Group Asia Report, no. 142, 2007. 
Hakim, Rahmat Nur. "BNPT Sebut Ada Masjid Terpapar Radikalisme Sejak 2012." https://nasional.kompas.com/read/2018/06/07/13221261/bnptsebut-ada-masjid-terpapar-radikalisme-sejak-2012. Diakses tanggal 6 Oktober 2018.

Hanafi, Muchlis Muhammad. "Hubungan Antar agama." Subuf Jurnal Pengkajian Alquran dan Budaya, vol. 1, no. 1 (2008).

Haryono, Endy. "Kebijakan Anti-Terorisme Indonesia: Dilema Demokrasi dan Represi." Jurnal Ilmu Sosial dan Ilmu Politik. vol. 14, no. 2 (2010).

Hasan, Noorhaidi. Laskar Jihad: Islam, Militancy, and the Quest for Identity in Post-New Order Indonesia. Ithaca: Cornell Southeast Asia Program Publications, 2006.

- Laskar Jihad: Islam, Militansi dan Pencarian Identitas di Indonesia Pasca Orde Baru. terj. Hairus Salim. Jakarta: LP3ES, 2008.

Hilmy, Masdar. "The Politics of Retaliation: The Backlash of Radical Islamists to Deradicalization Project in Indonesia." Al-Jami'ab: Journal of Islamic Studies, vol. 51, no. 1 (2013).

Istiqomah, Milda. "De-radicalization Program in Indonesian Prisons: Reformation on the Correctional Institution." Proceedings of the First Australian Counter Terrorism Conference. 5-7 Desember 2013.

KBBI, Tim Penyusun. Kamus Besar Bahasa Indonesia. Jakarta: Pusat Bahasa Depdiknas, 2008.

Kusmanto, Thohir Yuli, Moh. Fauzi dan M. Mukhsin Jamil. "Dialektika Radikalisme dan anti-Radikalisme di Pesantren." Walisongo Jurnal Penelitian Sosial Keagamaan, vol. 23, no. 1 (2015).

Movanita, Ambaranie Nadia Kemala. "Pelaku Teror Tahun 2017 Meningkat, Dua di Antaranya Lakukan Bom Bunuh Diri." https://nasional.kompas.com/read/2017/12/29/14252371/pelak u-teror-tahun-2017-meningkat-dua-di-antaranya-lakukan-bombunuh-diri.

Nuh, Nuhrison M. (ed.). Peranan Pesantren dalam Mengembangkan Budaya Damai. Jakarta: Badan Litbang dan Diklat Kementerian Agama, 2010.

Qaraḍāwī (al), Yūsuf. Al-Ṣaḥwah al-Islāmīyah bayn al-Juḥ̄d wa al-Tatarruf. Kairo: al-Taqwā, 2001.

Rokhmad, Abu. "Radikalisme dan Upaya Deradikalisasi Paham Radikal." Walisongo: Jurnal Penelitian Sosial Keagamaan, vol. 20, no. 1 (2012).

Schmid, Alex P.. Radicalisation, De-Radicalisation, Counter-Radicalisation: A Conceptual Discussion and Literature Review. Den-Haag, ICCT-The Hague, 2013. 
Sesmiarni, Zulfa. "Membendung Radikalisme dalam Dunia Pendidikan melalui Pendekata Brain Based Learning." Jurnal Kalam, vol. 9, no. 2 (2015).

Suharto, Toto dan Ja'far Assaqaf. "Membendung Arus Paham Keagamaan Radikal di Kalangan Mahasiswa PTKIN." Al-Tabrir Jurnal Pemikiran Islam, vol. 14, no. 1 (2014).

Sunaryo, Agus. "Masjid dan Ideologisasi Radikaslisme Islam: Menyoal Peran masjid sebagai Media Transformasi Ideologi." Akademika: Jurnal Pemikiran Islam, vol. 22, no. 1 (2017).

Syam, Nur. Tantangan Multikulturalisme Indonesia. Yogyakarta: Kanisius, 2009.

Tibi, Bassam. "Islamism and Democracy: On the compatibility of institutional Islamism and the political culture of democracy." Totalitarian Movements and Political Religions. vol. 10, no. 2 (2009).

Umar, Nasaruddin. Islam Fungsional, Revitalisasi dan Reaktualisasi Nilai-nilai Keislaman. Jakarta: PT. Gramedia, 2014.

Veldhuis dan Staun. Islamist Radicalisation: A Root Cause Model. Den Haag: Netherlands Institute of International Relations Clingendael, 2009.

Vidino, Lorenzo dan James Brandon. Countering Radicalization in Europe. London: ICSR, 2012.

\section{Internet}

https://alifmagz.com/whats-on/living-quran-ramaikan-pesta-

pendidikan-dalam-festival-publik-di-ambon. Diakses Tanggal 19 Agustus 2018.

https:/ /alifmagz.com/whats-on/tetes-embun-penyegar-dari-kegiatanliving-quran-di-pekan-2017-bandung/.

https://psq.or.id/program-2/.

https://www.bnpt.go.id/kepala-bnpt-berikan-paparan-dalam-rapatpleno-ke-25-mui.html. Diakses Tanggal 22 Juli 2018.

\section{Wawancara}

Wawancara dengan Ahmad Zayadi, Manajer Program PSQ.

Wawancara dengan Muchlis Hanafi, Direktur PSQ. 